\title{
Efficiency of Tibia Wetland in Treatment of Waste Water
}

\author{
Gitau, J. K. ${ }^{1^{*}}$ and Kitur, E. ${ }^{1}$ \\ Department of Environmental Sciences, Kenyatta University, Kenya. P.O Box 358-00216, Githuguri, Kenya.
}

\begin{abstract}
Information on wetland function in waste water treatment is very important as the information can be used to remove undesirable qualities of water. The aim of the study was to assess the effectiveness of natural wetlands in the treatment of waste water. The study was carried out for a period of four months (November 2012 to February 2013). Four sampling site were selected within the wetland and water samples were collected twice every week. Standard methods for sampling, storage and analysing according to APHA were used. Statistical analysis informs of T-test (2-tailed) and ANOVA were used to summarize the findings. The study revealed that the wetland played a role in the removal of pollutants where the best performance was obtained at TSS removal efficiency of 97.67\%. BOD, Chromium, Nitrate, Total Solids, and Phosphate ranged between 5096\% while conductivity and Total Dissolved Solids were less than 50\%. DO increased by $23.4 \%$ and $p H$ changed by $-0.79 \%$ hence the effluent water was less acidic as compared with influent water. The study concluded that Tibia wetland was effective and had potential in treatment of the waste water from the discharging facilities. It is recommended that wetlands can be conserved and used as waste water treatment facility instead of regarding them as waste land. Measures should be put in place to improve the final effluent quality to ensure that the levels of the parameters in the effluent are within the permissible limits.
\end{abstract}

Keywords: Physico-chemical parameters, Tibia wetland, Waste Water, Wetland.

\section{Introduction}

Wetlands are areas permanently or seasonally flooded by water (World Conservation Monitoring Centre, 1995). Wetlands are important to human as they perform a variety of functions. They provide ecological hydrological and Socio-economic functions (Dixon, 2003), source of rivers, storm water control, flow of water and acts as purification systems (world conservation monitoring Centre, 1995). Wetlands also acts as retention sink of nutrients from the catchment area, toxic waste and sediments (Enger and Smith, 2000). Wetlands are habitats and spawning and breeding grounds for many species of wildlife. Lake Tanganyika in Kenya has 214 species of fish, four-fifth of which are found nowhere else (World Conservation Monitoring Centre, 1995).

In Kenya, Wetlands are used for diverse purposes, including the treatment of waste water. Despite their widespread uses and distribution, our understanding on the effectiveness in waste water treatment remains limited. To harness their function in waste water treatment, it is important to find out their effectiveness in the removal of waste. Our limited understanding especially of their benefits partly explains their under-exploitation for waste water treatment.

Most wetlands in Kenya are small in size and located in areas of intense human activities. Tibia wetland in Limuru Municipality receives waste water from Limuru water and Sewerage Company and Bata Shoes Company. It is therefore likely that waste water from the two companies is treated as it passes through the Tibia Wetland. The effectiveness of the wetland in treatment of the waste water is limited yet most Companies and human activities release their waste into the wetlands. Information on the effectiveness of wetland on removal of waste forms vital baseline for use of wetlands as waste water treatment and also their conservation. The objective of the present study is to investigate the efficiency of Tibia wetland in treatment of the waste water following through it.

Tibia wetland in Limuru is a small size natural wetland which might be faced with extinction due to land pressure and overloading with waste, and if made useful especially as a waste water treatment plant, it can enhance its conservation and also reduced expenses involved in other methods of treating waste water. It is currently assumed that the Tibia wetland retains the nutrients, chemicals and pathogens carried with the wastewater, but there is no quantification of this function. Such information is necessary for the efficient planning of long-term sustainable use of the Tibia wetland.

\section{Study Area}

The study was carried out at Tibia wetland, which is located at the outskirts of Limuru town, Limuru District, in Kiambu County Kenya. The swamp is located along Kiambu-Tigoni road next to Limuru milk processing factory. Limuru District borders Lari to the West, Kikuyu to the East and is connected to Nairobi by Nairobi-Nakuru highway. Limuru is located at $1^{\circ} 06^{\prime} 26^{\prime \prime} \mathrm{S}$ and $36^{\circ} 37^{\prime} 53^{\prime \prime} \mathrm{E}$ (www.limurumunicipal.go.ke). 


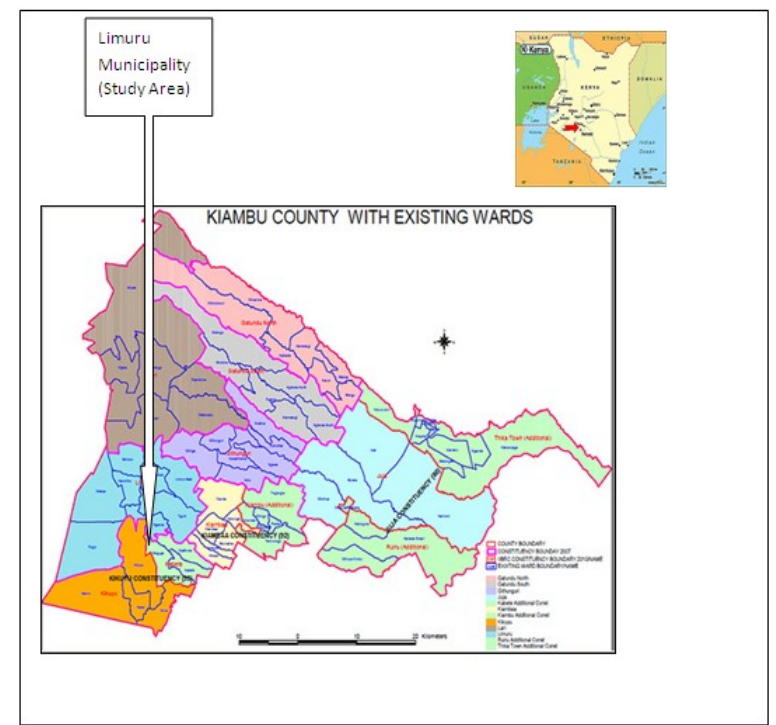

(Source: Flickriver.com)

Fig. 3.1: Map of Kiambu County showing Tibia Wetland the Study Area.

Water samples were collected from the wetland twice every month for a period of four month (November 2012 to February 2013). Four sampling points were identified which were Limuru Water and Sewerage Company inlet (LWSC), Bata Shoes Company inlet (BSC), Wetland and Wetland Outlet. Using a water scooper, water samples for laboratory analysis from each sampling point were collected at different depths and pulled together into a collection bucket to form a composite sample and transferred into I litre plastic bottles and capped. The amount of rainfall was also collected during the sampling period. The samples were transported to Nairobi Water and Sewerage Company laboratory for analyses. Samples analyses commenced within a period of four hours, sample preservation was in most occasions not necessary. The data was analysed using analysis of variance (Anova), T-test and Microsoft excel program. $\mathrm{P}<0.05$ was considered as minimum value for statistical significance.

\section{Temperature}

\section{Material and methods}

Water Temperature was determined with a temperature sensor of SensION $1 \mathrm{pH}$ meter: (HACH model with a Range: -2.00 to 19.99 and temperature: -10 to $100^{\circ} \mathrm{C}$ ). The probe was immersed in water allowed to equilibrate before temperature readings was taken and recorded in ${ }^{\circ} \mathrm{C}$.

PH

Water $\mathrm{pH}$ was measured using a SensION $1 \mathrm{pH}$ meter: (HACH model) with temperature compensation up to $19.9^{\circ} \mathrm{C}$. The $\mathrm{pH}$ meter was immersed into the water, allowed to equilibrate and the $\mathrm{pH}$ values on the meter read directly and recorded.

\section{Conductivity}

Electrical conductivity of the water was measured using a portable SensION 5 Conductivity meter, (HACH-USA with Range: 0 to $50000 \mathrm{mg} / 1$ and conductivity range: 20 to $199.9 \mu \mathrm{Scm}^{-1}$ ). The probe was immersed in the water allowed to equilibrate before the electrical conductivity was read and recorded in $\mu \mathrm{Scm}^{-1}$.

\section{Dissolved Oxygen}

Dissolved Oxygen in the water was measured using SensION 15b Dissolved Oxygen meter (HACH model with Range: $0-20 \mathrm{mg} / 1$ (ppm), (temperature: $0-50^{\circ} \mathrm{c}$ and accuracy: $1 \%$ full scale). The Dissolved Oxygen probe was immersed in the water and allowed to equilibrate before the readings of the dissolved Oxygen of the water sample was read and recorded in $\mathrm{mgL}^{-1}$.

\section{Biological Oxygen Demand}

BOD was determined using BOD bottle and aerated water samples. Dilution water (aeration water) was first prepared. A sample was pipette into a BOD bottle containing aerated dilution water. The DO content was determined and recorded and the bottle was incubated in the dark for five days at $20^{\circ} \mathrm{C}$. At the end of the five days, the final DO content was determined and the difference between the final DO reading and the initial DO 
reading was calculated. The decrease in DO was corrected for sample dilution, and represents the Biochemical oxygen demand of the sample.

\section{Total solids}

The amount of Total solids in water was determined gravimetrically; $100 \mathrm{ml}$ of well mixed sample was put into a special dish of known weight and then evaporated over a water bath to dryness. The residue was dried to a constant weight at temperature between $103-105^{\circ} \mathrm{C}$. The residue was cooled in a dessicator, weighed and results computed. The difference between the weight of the dish after and before the experiment gave the weight of the total amount of solids present in the sample.

\section{Total Suspended Solids}

The amount of Total suspended solids in the water sample was determined gravimetrically. A preweighed filter paper was used to filter $100 \mathrm{ml}$ of the water sample. The filter paper plus the precipitate were dried in an oven to a constant weight. The change in weight of the filter paper was the weight of the Total suspended solids in $100 \mathrm{ml}$ of the water sample.

\section{Total Dissolved Solids}

The amount of total dissolved solids in water was determined gravimetrically. Using filtered water samples, $100 \mathrm{ml}$ of the filtered sample was transferred to a weighted conical beaker and evaporated to dryness on a hot plate. The conical beaker plus the residual was cooled in a desiccator and then weighed. The difference between the weight of weighted beaker after and before the experiment gave the total amount of dissolved solids present in $100 \mathrm{ml}$ water sample.

\section{Nitrate-Nitrogen}

Nitrate-nitrogen concentration was determined by the modified Sodium salicaylate procedure (Scheiner 1974). Nitrate-nitrogen reacts with sodium salcylate in an acidic condition to form nitro salicylic acid. The salicylic acid turns yellow under alkaline conditions (APAH, 1998).Colour intensity was measured calorimetrically using a digital spectrophotometer (HACH MODEL). An amount of $5 \mathrm{ml}$ of filtered sample was put into a clean $50 \mathrm{ml}$ Nessler tube and $2 \mathrm{ml}$ sodium salicylate added and evaporated to complete dryness at $98^{\circ} \mathrm{C}$ in an oven. An amount of $1.0 \mathrm{ml}$ concentrated sulphuric acid was then added and allowed to dissolve for 10 minutes, $25 \mathrm{ml}$ distilled water was added followed by $5 \mathrm{ml}$ Rochell salt solution. Absorbance was read at $420 \mathrm{~nm}$. Standard of known $\mathrm{NO}_{3}-\mathrm{N}$ concentration was subjected to the same treatment as water sample and readings used to determine the actual concentration of nitrate in the sample.

\section{Total Phosphate}

Total phosphate concentration was determined using the ascorbic acid reduction procedure (APAH 1998). Unfiltered water was oxidized to $\mathrm{Po}_{4}-\mathrm{P}$ by autoclaving the samples at $120^{\circ} \mathrm{C}$ for 40 minutes using Ammonium persulfate oxidizing agent. Phosphate ions combine with ammonium molybdate to form a molybdophophate complex. The complex is readily reduced by ascorbic acid to an intensely blue phophomolydenium complex. Colour intensity was measured calorimetrically at a wavelength of $690 \mathrm{~nm}$ using a digital spectrophotomer (HACH Model).

\section{Chromium}

The concentration of chromium in the water samples was determined using a Shimadzu type Atomic Absorption Spectrophotometer (AAS) 6800 model with Air-C2H2 flame type of an average fuel flow rate of between 0.8-4.0 L min-1 and the support gas flow rate between 13.5-17.5 1/min was used for sample analysis.

The percentage removal efficiency is in most cases simply defined as: (Cin - Cout) / Cin x 100, where Cin and Cout are the inflow and outflow pollutant concentrations respectively. The negative values denote negative efficiencies.

PH

\section{Results And Discussions}

The $\mathrm{pH}$ at the wetland was 7.6 while at the wetland outlet it was 7.8. Variations in $\mathrm{pH}$ is attributed to microorganisms in water which breaks down organic materials to simpler products like $\mathrm{CO}_{2}$. The $\mathrm{CO}_{2}$ dissolves in water to produce carbonic acid $\left(\mathrm{H}_{2} \mathrm{CO}_{3}\right)$ which increases the $\mathrm{pH}$. The $\mathrm{pH}$ in water also comes from decaying vegetation and organic matter. Photosynthesis, and respiration are also responsible for variations of $\mathrm{pH}$ in water (Pidgeon \& Cains, 1987, Michaud, 1994). The $\mathrm{pH}$ recorded at the outlet could be attributed to breakdown of organic matter inside the wetland by micro-organisms into simpler products like carbon dioxide and water. The micro-organisms use oxygen for decomposition and gives out carbon dioxide. 


\section{Conductivity}

Electrical conductivity at the wetland was 1344.0 and at the wetland outlet it was 7.17. Conductivity in waste water is attributed to the presence of negative and positive ions (Gosselink \& Mitsch, 2000, Kumar \& Chopra, 2012), the amount of total dissolved solids, total suspended solids and diatomic nitrates in water (Shama et al., 2013). Decrease in the conductivity level after the wetland could be attributed to decrease in the concentration of TDS and TSS and the conversion of $\mathrm{NO}_{3}-\mathrm{N}$ into diatomic molecular nitrogen $\left(\mathrm{N}_{2}\right)$ as the concentration of charged ions decreases.

\section{Dissolved Oxygen}

At the wetland dissolved oxygen was 1.2 and at the wetland outlet it was 1.9. The amount of dissolved Oxygen in water is influenced by photosynthesis, respiration and decomposition, atmospheric oxygen and high organic matter (Bastviken, 2006, USDA, 1992). The slight increase in the level of dissolved oxygen at the outlet could be attributed to photosynthesis and biodegradation of compounds present in wastewater that previously used dissolved oxygen for various oxidation-reduction reactions and thus the release of oxygen through roots into the rhizosphere

\section{Temperature}

Temperature at the wetland was 17.5 while at the wetland outlet it was 16.4. Water temperature is influenced by time of the day, season and presence of vegetation and amount of dissolved solids (Michaud, 1994, water Protection Plan Development Guidebook, 2001). Low temperature at the outlet could be attributed to the shady effect of wetland vegetations and decreased organic matter concentration.

\section{Nitrate-Nitrogen}

The value of nitrate-nitrogen at the wetland was 39.2 while at the wetland outlet it was 4.2. Decrease in the concentration of nitrate-nitrogen can be as a result of denitrification ( Jameel , 1998, Sather \& Smith, 1984, Debusk \& Debusk, 2000, Kadlec \& Knight, 1996), uptake by vascular plants and subsequent burial when the plants die (Delaune et al., 1986). Low nitrate-nitrogen concentration recorded at the wetland outlet could be attributed to denitrification where nitrate is converted to diatomic molecular nitrogen, deposition of nitrate in sediments at the wetland bottom and plant uptake.

\section{Total Phosphate}

At the wetland the value of total phosphate was 12.6 and 1.8 at the wetland outlet. Decrease in the concentration of phosphate could be due to adsorption of phosphates onto mineral sediments. (Hemond \& Benoit, 1988). The presence of $\mathrm{Ca}^{2+}, \mathrm{Fe}^{3+}$ or $\mathrm{Al}^{3+}$ in sediments which determines adsorption capacity (Verhoen \& Arthur, 1999). type of vegetation and catchment. physical, chemical and biological processes (Kadlec \& Knight, 1996). Decrease could be attributed to plants uptake of the phosphate or some of it is deposited in the wetland bottom with sediments and adsorption.

\section{Biological Oxygen Demand}

Biological oxygen demand at the wetland was 917.2 while at the wetland outlet it was 38.9 . Wetland vegetation, decomposing micro-organisms and temperature influence the BOD in a water body contributes to low BOD (Hemond \& Bonoit, 1988, Steinmann et al., 2003). The noteworth reduction in $\mathrm{BOD}_{5}$ concentration at the outlet can be attributed to biodegradation of the organic matter by microbial bacterias in the wetland. The trapping of particulate organic matter by wetland vegetation, might have also contributed to decrease in $\mathrm{BOD}_{5}$ concetration at the outlet as the organic matter settle as sediment off the water column.

\section{TSS}

At the wetland total suspended solids was 5017.3 while at the wetland it was 59.6. Low velocity coupled with the presence of the luxuriant vegetation and gravel substrate contributes to lower TSS (Kadlec \& Knight, 1996). Removal of other pollutants like BOD, COD, heavy metals from the water also leads to decrease in TSS concentration. The decrease in TSS concentration noted at the outlet can be attributed to the luxuriant vegetation at the wetland which reduces speed of the water flowing through the wetland hence causing most of the suspended solids to settle from within the water column.

\section{TDS}

Total dissolved solids was 1251.8 at the wetland and 659.9 at the wetland outlet.Variations in concentrationof Total Dissolved Solids is attributed to presence of organic matter, . runoff, from urban areas road salt use in street fertilizers and pesticides used in farms. Inorganic materials and air that contains calcium 
bicarbonate, nitrogen, iron phosphorous, sulfur and other minerals (Lawson, 2011). The decrease in TDS noted at the outlet could be attributed to solid deposition due to reduced water speed as the water passes through the wetland. The decrease could also be attributed to uptake of some of the dissolved solids by wetland plants.

TS

At the wetland total solids was 6269.0 while at the wetland outlet it was 717.0. Low velocity coupled with the presence of the luxuriant vegetation and gravel substrate contributes to reduction in TS (Kadlec \& Knight, 1996). The decrease in the concentration of TS at wetland outlet might be as a result of reduced velocity of the waste water as it flows through the wetland due to the luxuriant wetland vegetation hence causing the solids to settle at the bottom or be attached on the roots of the wetland vegetations.

\section{Chromium}

Chromium at the wetland was 8.0 and 0.5 at the wetland outlet. Decrease in the concentration of chromium can be attributed to Accumulation on the roots surfaces of plants (Gosselink \& Mitsch, 2000). Traps or sinks onto wetland soils, accumulation in roots and leaves of wetland vegetation. Adsorption onto suspended sediment (mineral and organic), and buried in the sediment when it settles (Hemond \& Bonoit, 1988). Decrease in the concentration of the amount of chromium at Tibia wetland outlet could be attributed to plant roots and leaves accumulation or sinking into the wetland soil.

\subsection{Wetland removal efficiency of parameters from the waste water}

The study revealed that wetland plays a role in the removal of pollutants from waste water. The removal efficiency was different for the different physical and chemical parameters. The wetland removed $98.81 \%$ of TSS, BOD $95.76 \%$, chromium $93.75 \%$, nitrate $89.29 \%$, phosphate $85.71 \%$, TS $88.56 \%$ and TDS $47.28 \%$. The other parameter which improved after the waste water passed through the wetland were temperature and DO. The $\mathrm{pH}$ changed by $-2.63 \%$ (Table 4.3 ). The wetland efficiency in the removal of nitrate and phosphate could be attributed to plant uptake in the wetland and also since flow is reduced by resistance of the plants some of the nutrients settle in the sediments.

The efficiency in the removal of TS, TSS and TDS can mainly be attributed to reduced water speed inside the wetland hence the solids getting more time to settle off the water column while for BOD could be attributed to settling of organic matter with sediment and breakdown of the organic matter by micro-organisms into simpler compound like carbon dioxide and water. The improvement in DO could be attributed to reduced concentration of organic matter hence reduced demand for oxygen and pumping of atmospheric oxygen by wetland vegetation into the water.

Table 4.3: Table of the percentage removal of the physico-chemical parameters by the wetland and

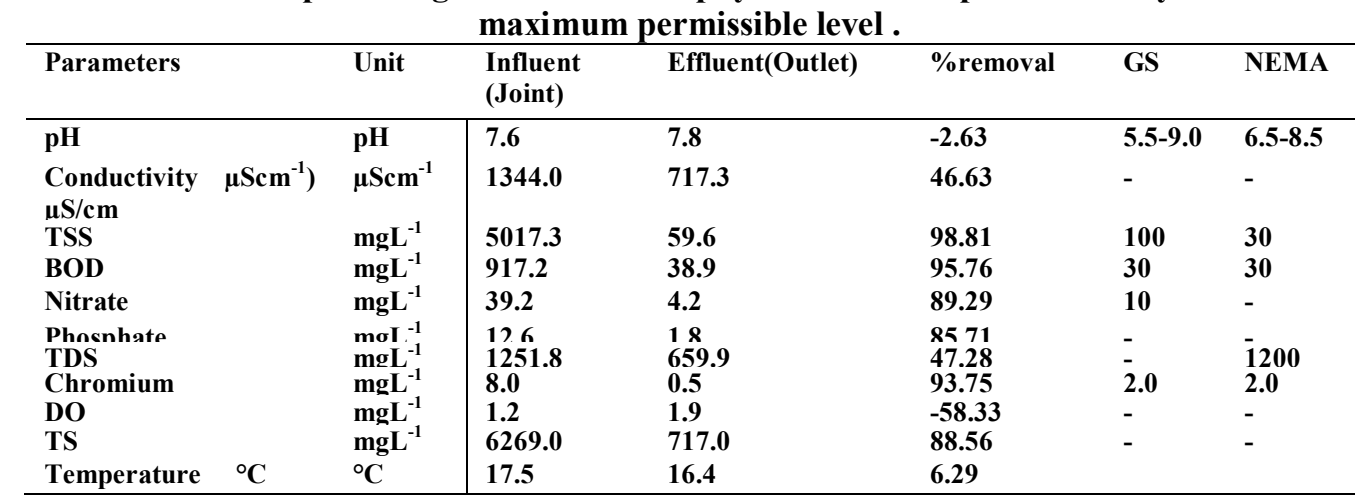

NEMA-Guidelines for discharge of effluent into the Environment as found in the Environmental Management and Coordination( Water Quality Regulations), 2006 Third schedule.

GS- Genaral Standards for discharge of Environmental pollutants (-Effluent) into inland water.

The parameters levels at the wetland are all as a result of discharges from Limuru Water and Sewerage Company and Bata Shoes Company. The changes observed at the wetland outlet can be attributed to several processes inside the wetland as discussed below.

\section{Conclusion}

The wetland had efficiency in removal of $98.81 \%$ TSS, BOD 95.76\%, Chromium 93.75\%, Nitrate $89.29 \%$, Total Solid $88.56 \%$ and Phosphate $85.71 \%$. In the case of conductivity and Total Dissolved Solids they were less than $50 \%$ at $46.63 \%$ and $47.28 \%$ respectively. Dissolved Oxygen concentration increased by $23.40 \%$ after the water passed through the wetland and $\mathrm{pH}$ changed by $-0.79 \%$ hence the effluent water was less acidic 
as compared with influent water (Table 4.3). For the parameters observed there was a significant difference between the wetland and wetland outlet except for DO, Temperature and $\mathrm{pH}$. From the comparison of water qualities of the waste water entering the wetland and that leaving Tibia wetland was effective in waste water treatment though its performance needs to be improved to meet the required standards.

Though the wetland was efficient in removal of pollutants and significantly improved water quality by reducing loads of the pollutants, some of the water quality parameters in the effluent water did not meet the required standards even after passing through the wetland. For the General Standards for discharge of environmental pollutants into inland surface water, TSS, $\mathrm{pH}$, Chromium, Nitrate-Nitrogen where within the permissible standards for discharge into surface water bodies as they were $59.6 \mathrm{mgL}^{-1}, 7.8,0.5 \mathrm{mgL}^{-1}, 4.2 \mathrm{mgL}^{-1}$ respectively while the permissible limits are $100 \mathrm{mgL}^{-1}, 5.5$ to $9.0,2.0 \mathrm{mgL}^{-1}$ and $10 \mathrm{mgL}^{-1}$ respectively. BOD failed to meet the General Standard as it was $38.9 \mathrm{mgL}^{-1}$ while the maximum permissible value is $30 \mathrm{mgL}^{-}$ ${ }^{1}$ (Table. 4.3).

From the NEMA standards $\mathrm{pH}$, Chromium, TDS were below the acceptable NEMA standards with values of $7.8,0.5 \mathrm{mgL}^{-1}$ and $659.9 \mathrm{mgL}^{-1}$ respectively while the permissible limits are $6.5-8.5,2.0 \mathrm{mgL}^{-1}$ and $1200 \mathrm{~mL}^{-1}$. BOD and TSS were higher than NEMA limits with values of $38.9 \mathrm{mgL}^{-1}$ and $59.6 \mathrm{mgL}^{-1}$ while the maximum permissible limits are $30 \mathrm{mgL}^{-1}$ for both (Table. 4.3).

\section{Acknowledgement}

I am very grateful to Dr. Esther Kitur and Dr. Gladys Gathuru for helping me to easily get access to appropriate literature and for giving me advice and encouragement during the writing of the manuscript. I am also grateful to Kenyatta University especially the department of environmental sciences for their support. Am obliged to all my family members and friends for their support and encouragement.

\section{References}

[1]. APHA (2005). Standard methods for the Examination of water and waste water. 20 $0^{\text {th }}$ Ed. America Public Health Association, Washington DC, USA.

[2]. Bastviken, S. K., (2006). Nitrogen removal in treatment wetlands-factors influencing spatial and temporal variations, PhD thesis, Linkoping University, Sweden.

[3]. Debusk, T. A. \& Debusk, W.F. (2000). Wetlands for water treatment. Edited by Kent, D. M., Lewis publisher, Boca Rota Florida.

[4]. Delaune, R.D., Smith, C. J. \& Sarafyal, M. N. (1986). Nitrogen cycling in a freshwater marsh of Panicum hemitomon on the deltaic plain of the Mississippi River. Journal of Ecology, 74: 249- 256

[5]. Dixon, B. A. (2003). Indigenous management of wetlands. Asbgate publishing limited, Ethiopia.

[6]. Enger, D. E. \& Smith, F. B., (2000). Environmental science. A study of interrelationships ( $7^{\text {th }}$ edition). Chapter 15 water management. Western Washington University.

[7]. Hemond, H. F. \& Bonoit, J. (1988). Cumulative impacts on water quality functions of wetlands. Environmental Management. 12(5): 639-653.

[8]. Kadlec, R. H., \& Knight R. L. (1996). Treatment Wetlands. CRC press/ Lewis Publishers, Boca Raton, Florida.

[9]. Kumar, V. \& Chopra, A.K., (2012). Monitoring of Physico-chemical and Microbiological Characteristics of Municipal Wastewater at Treatment Plant, Haridwar City (Uttarakhand) India. Journal of Environmental Science and Technology, 5: 109-118.

[10]. Lawson, E.O., (2011). Physico-chemical parameters and heavy metal contents of water from the mangrove swamps of Lagos Lagoon. Journal of Fish Biology, Lagos, Nigeria, Adv. Biol. Res., 5: 08-21.

[11]. Michaud, J. (1994). A citizen's Guide to Understanding and Monitoring Lakes and Streams. Washington State, Department of Ecology. pp 73.

[12]. Mitsch, W.J., \& Gosselink, J.G.. (2000). Wetlands. John Wiley and Sons, Inc, New York. 920 pp.

[13]. Pidgeon, R.,W.,J., \& Cains, S.C. (1987). Decomposition and colonization by invertebrates of nature and exotic leaf material in a small stream in New England (Australia). Hydrobiologia, 77: 13-124.

[14]. Sather, J. H. \& Smith, R. D. (1984). An overview of major wetland functions and values. Fish and Wildlife Service, U.S. Department of Interior Washington, DC.

[15]. Shama, S., Rabia, A., Iffat, N., Naeem, A., \& Safia, A. (2013). Reduction of contaminants (Physical, chemical and microbial) in Domestic wastewater through hybrid constructed wetlands. Retrieved November $12 \quad 2013 \quad$ from http://www.ncbi.nlm.nih.gov/pmc/articles/PMC3659477/.

[16]. Steinmann, C. R., Weinhart, S. \& Melzer, A. (2003). A combined system of lagoon and constructed wetland for an effective wastewater treatment. Journal of water resources. 37 pp 2035-2042.

[17]. United States Department of Agriculture (USDA). (1992). Agricultural Waste Management Building Design Handbook. Soil Conservation Service, Washington, D.C.

[18]. Verhoeven, J.T.A. \& Arthur, F.M.M. (1999). Wetlands for wastewater treatment: Opportunities and limitations. Ecological Engineering. 12:5-12.

[19]. Water protection guidebook. (2001). A guidebook for Local Governments for developing Regional Watershed protection plan. Retrieved October 102013 from http://www.gaepd.org/Files_PDF/techguide/wpb/devwtrplan.pdf

[20]. World Conservation Monitoring Centre (WCMC). (1995). Endangered lands!. World book international, Chicago. 